\title{
Pre-Service English Teachers' Perception on Higher Order Thinking Skills (HOTS) in English Language Teaching
}

\author{
Intan Armala, Endang Fauzia and Abdul Asib \\ Universitas Sebelas Maret \\ armalaintan@gmail.com
}

\begin{abstract}
Higher order thinking skill is one of the important components for an individual to be able to solve new problems in the 21th century. In the revised Bloom's taxonomy, HOTS is defined as an incision among the three top levels of ability in the cognitive dimension (analyzing, evaluating, creating), and 3 levels of knowledge dimension (conceptual, procedural, metacognitive). The aim of the present case study was to investigate pre-service English teachers' perception on Higher Order Thinking Skills in English language teaching. A total of 15 pre-service English teachers in a university in Indonesia participated in this study. The research used questionnaire to collect the data. Data were analyzed using interpretative approach. The result showed that the pre-service English teachers have their perspective about higher order thinking skills by themselves. They are aware towards Higher Order Thinking Skills in English language teaching. They are involving some activities to encourage students in thinking skill. They believed that every student is capable to think critically
\end{abstract}

Keywords: Pre-service English Teachers' Perceptions, HOTS, English Language Teaching 


\section{INTRODUCTION}

Nowadays, thinking ability is essential for people which to be more complex and sophisticated. People areasked to be able to solve countless problems and make various decisions. It is because of the effect of modernization and economic change. Information technology also plays the role as the cause of it. People are provided a lot of information which it is still confusing about the validity. So that people must be selective in choosing information.

In 21st century, education world demanded to meet the need of teaching and learning relate to thinking ability. From this case, the objective of people in education is to enhance their skill in problem solving and critical thinking. Hence, problem solving and critical thinking are emphasized in educational world. Many studies stated that a large proportion of what the teachers teach is what the teachers have learned. Therefore, it is essential to develop the knowledge in creative teaching to think critically and to be able to solve the problem.

Bloom taxonomy divides the educational objectives into three, namely cognitive, affective, and psychomotor domain. In cognitive domain of bloom taxonomy is classified six levels, namely knowledge, comprehension, application, analysis, synthesis, and evaluation. In affective domain is classified into five levels, namely receiving, responding, valuing, organizing, and characterizing. Meanwhile, in psychomotor domain is classified into seven levels, namely perception, set, guided response, mechanism, complex over response, adaptation, and organization. All of them is known as Bloom taxonomy (Weay, Masood, and Abdullah, 2016).

Basically cognitive levels consist of Lower Order Thinking skills (LOTS), Middle Order Thinking Skills (MODS), and Higher Order Thinking Skills (HOTS). In this case, remembering refers to lower order thinking skills, understanding and applying refer to middle order thinking skills and analysing, evaluating and creating include higher order thinking skills. Rajendra and Idris (2008) in Chidozie (2014), in Mursyid and Nia (2019) stated that higher order thinking skills involve the need of analysis, evaluation, and creation or production as thinking skills.

Higher order thinking skills is the important component and appropriate to educate the students today which has a complex situation in real life. As stated by Newman (1990) that higher order thinking skills are important for all learners. Many countries 
applied higher order thinking skills as the main component to develop the students to think critically and have the same level globally.

In Indonesia, the awareness of the importance higher order thinking skills also becomes a national educational goal. There is can be seen in the Law on the National Education System, Number 20 by years 2003: “... developing students' potential to become a critically, creatively, and independently citizen" (cited in Afandi, et al., 2018). However, according to Program for International Student Assessment (2009)revealed that thinking skill of students in Indonesia tend to have lower order thinking ability in understanding, complex information, theory, analysis, problemsolving, the use of tools and also investigating. Furthermore, Indonesian average scores of PISA are increased from the year of 2009 to 2015 (in Kusumastuti, Endang, and Sri, 2019).

Based on the phenomena above, the researchers want to investigate: 1) what is the perception of pre-service English teachers on higher order thinking skills in English Language Teaching?, and 2) What is the perception of pre-service English teachers relate to students' higher order thinking skills in English Language Teaching?

\section{Higher Order Thinking Skills}

The original of LOTS and HOTS was made by Benjamin S. Bloom in the 1950 in his work Taxonomy of Educational Objectives: The Classification of Educational Goals. Handbook I: Cognitive Domain. In this work, Bloom emphasized six categories of cognitive domain and provided definition for each of them:

1. Knowledge. This category includes different types of knowledge such as terminology, specific facts, conventions, trends and sequences, classifications and categories, criteria, methodology, principles and generalizations, theories and structures.

2. Comprehension. This refers to translation, interpretation, and extrapolation.

3. Application. This category refers to the "use of abstractions in particular and concrete situations.

4. Analysis. This category involves analysis of elements, of relationships, and that of organizational principles. 
5. Synthesis. The category represents production of unique communication; production of a plan or proposed set of operations; derivation of a set of abstract relations.

6. Evaluation. This means evaluation in terms of internal evidence and judgments in terms of external criteria.

In 2001 Lorin W. Anderson along with David R. Krathwohl revised the original taxonomy. They changed the names of major categories into verbs and used gerunds to interpret the meaning of each category, underscoring in this way the active nature of thinking process. In this research uses, the researcher uses the taxonomy described in A Revision of Bloom's Taxonomy: An Overview by David R. Krathwohl:

1. Remember (retrieving relevant knowledge from long-term memory): (1) Recognizing, (2) Recalling.

2. Understand (determining the meaning of instructional messages, including oral, written, and graphic communication): (1) Interpreting, (2) Exemplifying, (3) Classifying, (4) Summarizing, (5) Inferring, (6) Comparing, (7) Explaining.

3. Apply (carrying out or using a procedure in a given situation): (1) Executing, (2) Implementing.

4. Analyze (breaking material into its constituent parts and detecting how the parts relate to one another and to the overall structure or purpose): (1) Differentiating, (2) Organizing, (3) Attributing.

5. Evaluate (making judgments based on criteria and standards): (1) Checking, (2) Critiquing.

6. Create (putting elements together to form a novel, coherent whole or making an original product): (1) Generating, (2) Planning, (3) Producing.

According to Brookhart (2005) stated that higher order thinking comprehended as Bloom's cognitive taxonomy. The goal of cognitive taxonomies is facilitating the students to be able to do the transfer. "Being able to think" in this case means that students can use the knowledge and skills they constructed in a new contexts. "New" means that the students get the knowledge that they did not get before. Higher order thinking is understood as the students can be associated with their learning with other elements. 
Limbach\& Waugh, (2010) stated that to develop the ability to think critically, there are five lessons that can be taken, namely: (1) determine the learning objectives, (2) teach through inquiry, (3) practice, (4) review, refine and improve under-standing, and (5) practice feedback and assess learning. According to Krathworl (2002) indicators to measure the high-level thinking skills include: analyzing, evaluating, creating. Thus, HOTS is a thinking skill that not only requires the ability to re-member, but also other higher capabilities include the ability to analyze, evaluate, and create.

\section{Perception of Learning}

According to Sainn and Ugwuegbu (1980) perception is "the process by which we extract meaningful information from physical stimulation. It is the way we interpret our sensation" (p. 9o). They also classified three important points related to perception. First, perception relies on the stimulus and it is determined by individuals' experience, intention, and social needs. Second, the perceiver is actively choosing the information to formulate the hypothesis and decide what is actually taking place. Third, perception is a higher mental process which helps an individual build up a model of his or her world in order to help anticipate future happenings and deal with them appropriately. Therefore, the physical stimulation from sensory receptors of an individual give relatively limited information and cannot be interpreted unless there is additional information derived from past experiences and memory. Once the physical stimuli are appropriately interpreted, they will become the perceptions of an individual (cited in Choy and Cheah, 2009).

\section{METHOD}

This section discusses about research method. It presents three headings which consist of participant of this research, procedure and data collection and analysis.

1. Participant

In order to achieve the purpose of this research, 15 preservice English teachers were purposely chosen as a representative to investigate their perception about higher order thinking skills in English language teaching. The participants consist of 3 males and 12 females in a university of Surakarta, Indonesia. All participants have experience in teaching English at least 2 years. 
2. Procedure

In investigating the perceptions of pre-service English teachers about higher order thinking skills in English language teaching, the researchers used questionnaire to collect the data. The data were obtained from questionnaire transcript. After the researchers administered the questionnaire to the participants, the researchers interpret all the questionnaire transcripts by using interpretative approach. According to Radnor (2002) in interpretative approach, the individual builds their own meaning when they contend with the environment around them to make it meaningful, implying a need for an in-depth and insightful analysis of the data obtained. Holliday (2002) and Radnor (2002) added that the purpose of this approach is to see the reality socially as being built where the personal behaviours are being interpreted and reinterpreted to give meaningful interpretation within a particular context.

3. Data Collection and Analysis

In this research, the researchers are using qualitative in the type of case study. According to Cresswell (2009), case study is a strategy of inquiry in which the researchers explores in depth a program, event, activity, process, on one or more individuals. Therefore, the researchers used case study to investigate the perceptions of pre-service English teachers on higher order thinking skills in English language teaching.

The qualitative data was collected through questionnaire to the participants. All of pre-service English teachers participate in answering the questionnaire to get the results based on the goals of this research. The questionnaire protocol is adapted from Coffman (2013). The questionnaire consists of 8 questions that must be filled by the participants.

\section{RESEARCH FINDINGS AND DISCUSSION}

$R Q$ 1. What is pre-service English teachers' perception on higher order thinking skills (HOTS) in English language teaching (ELT)?

The finding of research question 1 was attained from two categories. First category was the participants or pre-service English teacher perception on higher order thinking skills (HOTS) based on the definition of higher order thinking skills. Second category was their perception of practicing higher order thinking skills (HOTS) in English language teaching (ELT). 
Pre-service English teachers' definition on higher order thinking skills (HOTS) in English language teaching (ELT). Mostly the participants define higher order thinking skills as thinking skills which involve critical thinking and creative thinking in solving problem. As stated by many participants, they noted that;

"Higher order thinking skills require students to have a more critical thinking to analyse and solve a problem in language learning itself". Miss I

"Higher order thinking skills are skills which require students to think critically in solving problem". Miss S

"Higher order thinking skills is the process of thinking autonomously and critically to encounter problems". Mr. A

Many participants also explain that higher order thinking skills are skills which more than activities like remembering, memorizing, and recalling. As stated by many participants

"Higher order thinking skills are thinking skills which more than remembering that encourages students to think critically and creatively". Miss V

"Higher order thinking skills are higher level cognitiveskill which higher than memorizing and recalling". Miss L

The finding indicates that the participants have their own perspective in defining higher order thinking skill. Most of them perceived that higher order thinking skills is skills that involve activities to think critically and creatively in solving problem. They also believe that higher order thinking skills encourage students to explore their mind and analyse the issue in different angle.

Pre-service English teachers' perception in practicing higher order thinking skills in English language teaching. All of the participants have experience in practicing higher order thinking skills in English language teaching. They also can see when higher order thinking skills occurs in classroom. Many of them see higher order thinking skills occur in English language teaching is when the students can find the solution and give reason of certain problems. As commented by Miss R, Miss I and Miss S

"I can see higher order thinking skills used in English language teaching when the students are able to overcome the problems by theirselves". Miss R

"I will see higher order thinking skills in English language teaching by inviting the students to see much phenomenon that can be criticized". Miss M 
"Higher order thinking skills occur in English language teaching is when the students capable to give a reason in answering certain question in deep". Miss S

A participant also used an approach to see higher order thinking in English language teaching. She perceived that using an approach can encourage students to think critically. As stated by Miss B;

"I will apply technology learning combined with suitable pedagogy and content (TPACK) to encourage students to think more deeply". Miss B

From the finding above, it showed that pre-service English teachers perceived that they see higher order thinking skills when they involve some activities to push the students criticize a certain phenomenon which needs critical thinking to solve the problem. They also use approaches in English language teaching to support the student in thinking deeply.

$R Q$ 2. What are pre-service English Teachers' perceptions of students' ability on higher order thinking skills in English language teaching?

In answering the research question 2, the finding consists of two categories: a) pre-service English teachers' perception on students' demonstration of higher order thinking skills in English language teaching, and b) pre-service English teachers' perception of the whether or not students capable to think critically.

Pre-service English teachers' perceptions on demonstrating students' higher order thinking skills in English language teaching.

Majority of the participants perceived that students will be able to build their higher order thinking skills through involving some activities to stimulate them. Some activities that requires analysing and reasoning so that the students will be active in learning process. It stated by one of the participants

"I will use flipped learning. The students will solve the questions given by exploring and experimenting by themselves. It also accustoms themselves to be autonomous". Mr. A

Majority of the participants also explained that through questioning, answering, discussing in group work or role play is able to encourage students to explore their ideas and opinions. As stated by Mr. N and Miss B 
"I will give the students some kinds of questions then I will conduct the discussion. Through the discussion, I will be able to know the way students think". Mr. N

"It can be work group or project based activities which build students' higher order thinking skills". Miss B.

Through some activities involving higher order thinking skills in English language teaching, the participants or pre-service English teachers realize that students are doing higher order thinking skills by themselves. They stated that the students are doing higher order thinking skills when the students capable to find solution, analyse problems, give the reasons which it requires deep thinking. The participants commented that;

"The students are doing higher order thinking skills automatically when they find solution of the problems which are not provided or explained by teachers before". Miss F

"Through some activities which stimulate the students' higher order thinking skills, unconsciously the students are doing higher order thinking skills by showing multiple solutions, produce reasoned critique, etc.". Miss M

"In the way that the students explain certain things clearly with reasonable reasoning, they are doing higher order thinking skills". Miss B

The finding showed that to build students' higher order thinking skills, it is involving certain activities relate to learning process. This certain activities will motivate the students to think deeply and can find the solution of the problem by analyse and criticize it so that they can overcome and produce the reason.

Pre-service English teachers' perception of the whether or not students capable to think critically. Majority of the participants believed that all of the students are capable to think critically. However, one of them said that each student has their own in thinking skills whether the students tend to lower order thinking skills or higher order thinking skills. Hence, they perceived that every student needs process and take more effort so that they will be able to acquire higher order thinking skill in their learning. It is stated by many of the participants

"Yes, students are capable of thinking critically. Every student are unique, we just need to put more efforts so that they can develop equally". Miss E 
"Yes, I do. It just needs some practice. If they do it often, is they repeat over and over again, they will be used to it". Miss V "All of the students are capable to think critically but with their own level"

It can be said that to make the students capable in critical thinking, it needs long process and more effort to let the students adjust with their thinking skills especially higher order thinking skills. It will be the challenge for the educators to bring the students into higher order thinking skills.

In evaluating the students' higher order thinking skills, preservice English teachers used some of assessment to see thinking skill of the students. Most of them used rubric for scoring the students in particular learning activities. As stated by many participants

"I will use higher order thinking skills rubric assessment to evaluate the students" Miss B

"I will assess the students' thinking skill by using appropriate rubric" Miss S

"It can be using rubric, discussion and summative test to evaluate the students' higher order thinking skills" Mr. A

Many of the participants also used activities as their evaluation toward students' higher order thinking skills. As stated by many of the participants

“... I will do discussion to build the students' higher order thinking skills. I should tell them from the very beginning that they should be active on that discussion. The more active they are the higher score they will get" Miss V

"I will make a bloom taxonomy check list based on the question items answered by the students" Mr. N

From the finding, to evaluate students' thinking skills, the pre-service English teachers used various ways in determining students' critical thinking. Rubric score, performance, the activeness of the students, etc. were used by pre-service English teachers in assessing their students.

\section{CONCLUSION}

Majority of the participants have their own perspective about higher order thinking skills. They were aware of the existence higher order thinking which it is an essential component in teaching and learning especially in English language teaching. They 
defined higher order thinking skills as thinking skills that involve critical thinking and creative thinking in solving the problems. They infuse higher order thinking skills in English language teaching through some activities which capable to encourage the students to think critically. They also used approaches to stimulate the students in criticize certain problem and hoped that the students can solve and generate idea through particular problems.

Pre-service English teachers also make assessment to see the involvement of higher order thinking skills in students' learning process. Most of them used appropriate rubric assessment to evaluate students' thinking skills. They also see the students' higher order thinking skill through their activeness when they are criticizing, responding, or expressing idea of the phenomenon they faced. All the participants believed that every student is capable to think critically. They believed that take more process and efforts will make the students have higher order thinking skills.

\section{REFERENCES}

Afandi, et al. (2018).Pre-service English Teachers Perception about Higher Order Thinking Skills (HOTs) in $21^{\text {st }}$ Century.International Journal of Pedagogy and Teacher Education (IJPTE) 2(1).

Bloom B.S. (Ed.), Engelhart M.D., Furst E.J., Hill W.H. \&Krathwohl D.R. Taxonomy of educational objectives: The classification of educational goals, US, Handbook 1: Cognitive domain, 1956.

Choy, S. \&Cheah, P. (2009).Teacher Perception of Critical Thinking among Students and its Influence on Higher Education.International Journal of Teaching and Learning in Higher Education, 20(2), 198-206.

Holliday, A. R. (2002). Doing and Writing Qualitative Research. London: Sage.

Kusumastuti, I., Endang F., and Sri M. (2019).Revealing Teachers' Beliefs of Higher Order Thinking Skills in Teaching Reading at Junior High School.English Language and Literature International Conference (ELLiC) Proceedings Vol. 3.

Krathwohl D.R. A Revision of Bloom's Taxonomy: An Overview, Theory into Practice, US, vol 41/number 4, pp 212 - 218, 2002. 
Limbach, B. and Waugh, W. (2010).Developing Higher Level Thinking.Journal of Instructional Pedagogies, 3.http://www.aabri.com/manuscripts/og423.pdf.

Mursyid and Nia Kurniawan.(2019). Higher Order Thinking Skills among English Teachers across Generation in EFL Classroom.Journal of English Education 7(2).

PeraturanMenteriPendidikandanKebudayaanRepublik Indonesia No. 22 Tahun 2016 TentangStandar Proses PendidikanDasardanMenengah. Retrieved on February 9th, 2019 from https://bsnp-indonesia.org

Radnor, H. A. (2002). Researching your Professional Practice: Doing Interpretive Research. London: Open University Press.

S. Brookhart, "How to Assess Higher-Order Thinking Skills in Your Classroom". ASCD Publications, 2010.

Weay, A. L., Masood, M., \& Abdullah, S. H. (2016).Systematic review of revised Bloom Taxonomy, SOLO Taxonomy and Webb's Depth of Knowledge (DOK) in assessing students' historical understanding in learning history.Malaysian Journal of Higher Order Thinking Skills In Education, 1-27. 